\title{
New Nuclease from Extremely Psychrophilic Microorganism Psychromonas ingrahamii 37: Identification and Characterization
}

\author{
Natalia Maciejewska ${ }^{1} \cdot$ Rafał Walkusz $^{2} \cdot$ Marcin Olszewski $^{2} \cdot$ Aneta Szymańska $^{1}$ (I)
}

Published online: 11 December 2018

(c) The Author(s) 2018

\begin{abstract}
Nucleases are an important group of hydrolases that degrade nucleic acids, with broad spectrum of applications in science and industry. In this paper, we report the identification and characterization of the nuclease from extremely psychrophilic bacterium Psychromonas ingrahamii that grows exponentially at $5^{\circ} \mathrm{C}$, but may also grow at even lower temperatures (down to $-12{ }^{\circ} \mathrm{C}$ ). The putative endonuclease I gene, identified in the genome of P. ingrahamii, was cloned and expressed in Pichia pastoris. The recombinant protein was purified and its nucleolytic features were studied. The new enzyme, named by us as PinNuc, displays the features characteristic for the nonselective endonucleases, and has the ability to degrade different forms of nucleic acids. It is very active at room temperature in low ion-strength buffer and in the presence of low concentrations of magnesium ions. The enzyme, which possesses six cysteine residues, the most likely all engaged in disulphide bridges, is active only in oxidized form, and can be efficiently inactivated by the addition of low amounts of a reducing agent. According to our knowledge, it is the first nuclease, belonging to endonuclease I family, isolated from such extremely psychrophilic organism.
\end{abstract}

Keywords Nuclease $\cdot$ Psychrophilic $\cdot$ Substrate specificity $\cdot$ Psychromonas ingrahamii $37 \cdot$ Enzymatic activity $\cdot$ Cold-active enzyme

\section{Introduction}

The biggest part of the Earth's biosphere, accounting for approximately $85 \%$, is the psychrosphere, with temperatures below $5{ }^{\circ} \mathrm{C}[1]$. This is also the least studied part of it, especially when it comes to the microorganisms inhabiting the cold regions. The obvious reason is the difficulty involved in

Aneta Szymańska

aneta.szymanska@ug.edu.pl

Natalia Maciejewska

n.maciejewska@gmail.com

Rafał Walkusz

rafalwalkusz@gmail.com

Marcin Olszewski

molsza@wp.pl

1 Department of Biomedical Chemistry, Faculty of Chemistry, University of Gdańsk, ul. Wita Stwosza 63, 80-308 Gdańsk, Poland

2 Department of Molecular Biotechnology and Microbiology, Faculty of Chemistry, Gdańsk University of Technology, ul. Narutowicza 11/12, 80-233 Gdańsk, Poland their acquisition. These organisms are, however, very interesting due to the unique mechanisms they evolved to survive in such extreme conditions [2]. Apart from strictly scientific, industrial and commercial interests also fuel new discoveries in the field of cold-adapted, bioactive compounds [3, 4]. The psychrophilic enzymes are currently utilized as biocatalysts in many biotechnological processes related to food processing, detergent production, biotransformation, and other [3, 5]. Due to growing demands for new, effective, and, most of all, environment-friendly biotechnological processes (socalled "Next Generation Industrial Biotechnology" [6]) the interest in extremophiles, especially psychrophiles, is also growing.

The utilization of cold-adapted enzymes makes it possible to reduce the costs of the biotechnological processes as a result of the lower energy consumption involved [7, 8]. Moreover, the unique features of these enzymes, such as their activity at low temperatures, broaden their range of applications. This is extremely important in the case of nucleases, as it will allow their utilization for the elimination of nucleic acids from thermosensitive preparations. Nucleases are very important enzymes belonging to the group of hydrolases that 
degrade nucleic acids [9]. Due to their substrate specificity, nucleases are valuable biotechnological tools, with a potentially very broad spectrum of applications, not only in laboratories, but also on an industrial scale, especially in the modern pharmaceutical industry [10]. The production and purification of a nuclease from psychrophilic organisms will permit its application as a very valuable molecular biology tool. Currently, there is one commercially available nuclease isolated from a psychrotrophic Shewanella sp. strain AC10 [11] called Cryonase $^{\mathrm{TM}}$ (Takara, Japan), one obtained from mesophilic bacterium Serratia marcescens (Benzonase ${ }^{\circledR}$; Merck) and one of unrevealed origin (HL-SAN; Heat-Labile Salt Active Nuclease; ArcticZymes). Apart from those, there are also other endonucleases with a broad substrate activity, isolated from psychrophilic, psychrotolerant, and mesophilic organisms described in the literature [12-17].

In this paper, we describe cloning, expression, purification and biochemical characterization of a new nuclease from extremely psychrophilic bacterium Psychromonas $\backslash$ ingrahamii. P. ingrahamii belongs to the Gammaproteobacteria, Psychromonadaceae family and was first isolated in 1991 from a sea ice core collected in Alaska, USA [18, 19]. The bacterium lives in a neutral habitat with optimal $\mathrm{pH}$ range from 6.5 to 7.4, sodium chloride concentrations of 1 to $10 \%$, and at temperatures of -12 to $10^{\circ} \mathrm{C}$. The optimal growth temperature is $5{ }^{\circ} \mathrm{C}$ with no growth observed above $15^{\circ} \mathrm{C}[20]$. P. ingrahamii was also shown to be able to proliferate at $-12^{\circ} \mathrm{C}$, which is the lowest temperature noted for any organism [19]. The genome of P. ingrahamii is approximately $4.5 \mathrm{Mb}$ and the $\mathrm{G}+\mathrm{C}$ content reaches $40 \%$ [21]. The phylogenetic analysis of the 16S rRNA gene sequence shows that the bacterium is closely related to the psychromonas type [20].

The PinNuc enzyme was obtained in Pichia pastoris, purified to homogeneity, and its activity tested on a range of substrates representing different forms and types of nucleic acids. The obtained results allowed to ascribe the PinNuc to the endonuclease I-type family of nucleases with a broad spectrum of activity. The enzymes show similar low-substrate selectivity, high activity at low to moderate temperatures, and can be efficiently deactivated by the addition of a reducing agent. The reported nuclease is expected to extend the available portfolio of cold-adapted bioactive compounds with good prospect in its application in molecular biology, and biotechnological industry, as well as an alternative to its analogues already available on market.

\section{Materials and Methods}

\section{Bacterial Strains, Plasmids, Enzymes and Reagents}

Psychromonas ingrahamii 37 (DSM 17664) was purchased from The Leibniz Institute DSMZ (German Collection of
Microorganisms and Cell Cultures, Germany). Genomic sequence for this strain is available in the GenBank (accession no. CP_000510). The Escherichia coli TOP10 (Invitrogen, USA) was used for genetic constructions. P. pastoris GS115 (Invitrogen, USA) was used for gene expression. The pGAPZ $\alpha$ B plasmid (Invitrogen, USA) was used for constructing the expression system. The reagents for PCR were obtained from A\&A Biotechnology (Poland) and Blirt S.A. (Poland). Specific primers were purchased from Sigma-Aldrich (Poland). The restriction enzymes were purchased from NEB (USA).

\section{Construction of the Expression Plasmid}

Genomic DNA from P. ingrahamii 37 was extracted using the ExtractMe DNA Bacteria Kit (Blirt S.A./DNA-Gdańsk, Poland). The specific primers for PCR amplification were designed, and synthesized on the basis of the known nuclease gene sequence from $P$. ingrahamii. The forward primer was PinNucXhoI 5' GGAGGACTCGAGAAAAGAATG GCTGGCAACACCACCAAGGA (41 nt containing a XhoI recognition site, ATG start codon, italicized) and reverse primer-5' GGATTATCTAGATTACCATAACCC TTTATCCGTACATC (38 nt containing a XbaI recognition site, UUA stop codon, italicized). The boldface parts of the primers' sequences are complementary to the nucleotide sequences of the nuclease gene, whereas $5^{\prime}$ overhanging ends of primers contain recognition sites for restriction endonucleases (underlined) and are designed to facilitate cloning. The PCR reaction solution consisted of $0.2 \mu \mathrm{g}$ of $P$. ingrahamii 37 genome DNA, $1 \mu \mathrm{l}(10 \mu \mathrm{M})$ of each primer, $2.5 \mu \mathrm{l}(10 \mathrm{mM}) \mathrm{dNTPs}, 1 \mu \mathrm{l}(25 \mathrm{mM}) \mathrm{MgCl}_{2}$,

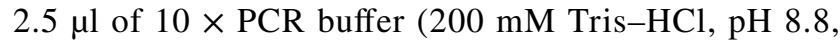
$100 \mathrm{mM} \mathrm{KCl}, 100 \mathrm{mM}\left(\mathrm{NH}_{4}\right)_{2} \mathrm{SO}_{4}, 1 \%$ Triton $\left.\mathrm{X}-100\right)$ and 2U Pwo DNA polymerase (Blirt S.A., Poland). 30 cycles were performed using the Veriti ${ }^{\circledR} 96$ Well Thermal Cycler (Applied Biosystems, USA), with a temperature profile of $30 \mathrm{~s}$ at $94{ }^{\circ} \mathrm{C}, 30 \mathrm{~s}$ at $55{ }^{\circ} \mathrm{C}$ and $30 \mathrm{~s}$ at $72{ }^{\circ} \mathrm{C}$. The amplification products were analyzed by electrophoresis on $1 \%$ agarose gel stained with ethidium bromide. Specific, approximately $705 \mathrm{bp}$, PCR products were identified and purified using the ExtractMe Gel-Out Kit (Blirt S.A., Poland). The PCR product was digested with $\mathrm{XhoI}$ and $X b a \mathrm{I}$ (NEB, USA), purified using an ExtractMe Clean-Up Kit (Blirt S.A., Poland) and ligated into pGAPZ $\alpha B$ plasmid (Invitrogen, USA) between the $\mathrm{XhoI}$ and $\mathrm{XbaI}$ sites. The $E$. coli TOP10 cells were transformed with the ligation mixture and 30 colonies were examined for the presence of the nuclease gene from $P$. ingrahamii, using a gel retardation assay and restriction analysis. One clone was selected and sequenced to confirm the presence of the target gene. 


\section{Protein Sequence Analysis}

PinNuc amino acid sequence was analyzed using the online available resource BLAST [22]. Sequence alignments were performed with ClustalX software, using a PAM 500 scoring matrix. The visualization and rendering of the results was performed using ESPript 3 [23].

\section{Yeast Transformation and Expression}

Pichia pastoris GS115 strain was grown in an yeast extract peptone dextrose (YPD, $1 \%$ yeast extract, $2 \%$ peptone, $2 \%$ dextrose) medium and prepared for transformation. $10 \mu \mathrm{g}$ of plasmid DNA was linearized using an AvrII restriction enzyme and then transformed into P. pastoris cells by electroporation. After incubation for $3 \mathrm{~h}$ at $30^{\circ} \mathrm{C}$ in $1 \mathrm{M}$ sorbitol without agitation, cells were plated in the YPD Zeocin agar medium ( $100 \mu \mathrm{g}$ zeocine $/ \mathrm{ml}, 2 \%$ agar) to screen for the integration of the transformed gene into the GAP region of the host chromosomal DNA. The positive transformants were identified by direct PCR screening.

Transformants were grown in a shaking $(200 \mathrm{rpm})$ culture at $30{ }^{\circ} \mathrm{C}$ to an optical density at $600 \mathrm{~nm}\left(\mathrm{OD}_{600}\right)$ between 5 and 6. Optimal levels of expression were determined for each recombinant system and, after the optimal time of growth giving the highest protein expression, the cells were harvested by centrifugation $(15 \mathrm{~min}, 5000 \times \mathrm{g})$. The cell-free supernatant was analyzed and purified.

\section{Purification of the Recombinant Protein PinNuc}

All purification procedures were carried out at $4{ }^{\circ} \mathrm{C}$. The clear culture filtrate, obtained after centrifugation of a growth culture as described above, was brought to $30 \%$ saturation by the addition of solid ammonium sulfate. The precipitate was removed by centrifugation $(30 \mathrm{~min}, 10,000 \times \mathrm{g}$ ). Further addition of ammonium sulfate to the supernatant to a $70 \%$ saturation resulted in precipitation of the enzyme which was collected by centrifugation $(30 \mathrm{~min}, 10,000 \times \mathrm{g})$ and dissolved in $20 \mathrm{mM}$ Tris- $\mathrm{HCl}, 0.5 \mathrm{M} \mathrm{NaCl}$, and $20 \%$ glycerol (pH 8.0) buffer. The recombinant protein was purified using $\mathrm{Ni}^{2+}$ affinity chromatography. The supernatant containing PinNuc was loaded directly onto an HisBind Column ( $2 \mathrm{ml}$, Novagen, USA), previously equilibrated with $50 \mathrm{ml}$ of buffer A (20 mM Tris- $\mathrm{HCl}$ pH 8.0, $0.5 \mathrm{M} \mathrm{NaCl}, 5 \mathrm{mM}$ imidazole, and $20 \%$ glycerol). The PinNuc was eluted with a 5-300 mM linear imidazole gradient. The eluted fractions were analyzed, collected, and dialyzed to $20 \mathrm{mM}$ Tris- $\mathrm{HCl}$ ( $\mathrm{pH} 8.0$ ), $20 \mathrm{mM} \mathrm{NaCl}$, and $50 \%$ glycerol buffer. The purity of the PinNuc fractions was assessed using SDS-PAGE. Pure protein, obtained after metal-affinity chromatography, was dialyzed against $20 \mathrm{mM}$ Tris, pH 7.5, $20 \mathrm{mM} \mathrm{NaCl}$, and 50\% glycerol buffer, concentrated using Amicon Ultra Centrifugal Filter Unit (MWCO $10 \mathrm{kDa}$, Millipore) and stored at $-80^{\circ} \mathrm{C}$.

\section{Optimization of the Reaction Conditions}

The optimization of the conditions ensuring the best performance of the obtained enzyme was performed using the genomic DNA isolated form E. coli (ExtractMe DNA Bacteria Kit, Blirt S.A., Poland). Isolated DNA (200 ng/ $\mu$ l) was subjected to the hydrolysis by the nuclease $(1 \mu \mathrm{l}, 1 \mu \mathrm{g} / \mathrm{ml})$ in the buffers of varying composition. The volume of the reaction mixture was $20 \mu \mathrm{l}$.

The following parameters were optimized:

a. Divalent cations necessary for effective DNA cleavagefor this purpose $\mathrm{Mg}^{2+}$ (as $\left.\mathrm{MgCl}_{2}\right), \mathrm{Mn}^{2+}$ (as $\mathrm{MnCl}_{2}$ ) and $\mathrm{Ca}^{2+}\left(\right.$ as $\left.\mathrm{CaCl}_{2}\right)$ ions at $0,2,4,8,16,32,64,128$, $256 \mathrm{mM}$ concentrations were used in separate reactions; respectively;

b. The presence of $\mathrm{K}^{+}$and $\mathrm{Na}^{+}$ions- $-\mathrm{NaCl}$ or $\mathrm{KCl}$ at concentrations $0,2,4,8,16,32,64,128,256$ and $512 \mathrm{mM}$ were included in the reaction mixture and evaluated with regard to the effectiveness of the hydrolysis reaction;

c. The effect of $\mathrm{pH}$ - the effectiveness of the reaction was tested in the $\mathrm{pH}$ range of 4.0-9.5 using citrate buffer and Tris-HCl buffers;

d. Temperature-by carrying the DNA hydrolysis at 15 , $20,25,30,35,40,45,50$ and $55^{\circ} \mathrm{C}$, respectively;

Apart from the reactions aiming at determination of the optimal temperature, all reactions were carried out at $30^{\circ} \mathrm{C}$ for $30 \mathrm{~min}$. To check the progress of the reaction, the absorbance of the reaction mixture at $260 \mathrm{~nm}$ wavelength and the DNA concentration in the sample were measured using NanoDrop instrument (Perkin Elmer, Lambda Bio).The relative activity of the enzyme was calculated using the following equation:

relative activity $[\%]=\frac{c_{0}-c_{k}}{c_{0}} \times 100 \%$

where $c_{0}$ is the initial DNA concentration in the sample and $c_{\mathrm{k}}$ is DNA concentration in the sample after incubation with PinNuc nuclease at given experimental conditions.

The reaction products were also separated using electrophoresis on $1 \%$ agarose gel run in Tris-acetate-EDTA (TAE) buffer. DNA fragments were visualized using ethidium bromide under UV light and the obtained images were digitalized using an in-house build gel-doc system.

\section{Thermostability and DTT Sensitivity}

The stability of the enzyme was checked by incubating the protein at different temperatures and times. PinNuc was 
incubated at temperatures ranging from 30 to $99{ }^{\circ} \mathrm{C}$ during 5 to $60 \mathrm{~min}$. After each denaturation, an activity test was performed using the optimal conditions for DNA hydrolysis established in earlier experiments. Briefly, $77 \mathrm{ng}$ of pUC19 plasmid (amplified and isolated from in E. coli using ExtractMe Plasmid DNA Kit, Blirt S.A., Poland), was digested at $30{ }^{\circ} \mathrm{C}$ for $30 \mathrm{~min}$ in reaction buffer consisting of $50 \mathrm{mM}$ Tris- $\mathrm{HCl} \mathrm{pH} 7.5$ and $4 \mathrm{mM} \mathrm{MgCl}_{2}$. The hydrolysates were separated using electrophoresis on $1 \%$ agarose gel run in TAE buffer. DNA fragments were visualized using ethidium bromide $(1 \mu \mathrm{M})$ under UV light and the obtained images were digitalized using VersaDoc molecular imager system (Bio-Rad).

To test the effect of the reducing agent addition on the enzymatic integrity of the studied enzyme, dithiothreitol (DTT) at $1 \mathrm{mM}$ and $5 \mathrm{mM}$ was added to the PinNuc solution and the mixture was incubated at $99^{\circ} \mathrm{C}$ for a given time period followed by the performance of an activity test as described above. In another approach, the enzyme solution was incubated in the presence of $1 \mathrm{mM}$ DTT for $15 \mathrm{~min}$ at varying temperature conditions.

\section{Substrate Specificity}

The substrate specificity of the PinNuc enzyme was examined using various forms of deoxynucleic acid and ribonucleic acid. The reactions were carried out at previously optimised conditions and the hydrolysates were analysed as described above. Briefly, 200 ng of pUC19 plasmid (amplified and isolated from in E. coli using ExtractMe Plasmid DNA Kit, Blirt S.A., Poland) or 200 ng of genomic DNA (amplified and isolated form E. coli using ExtractMe DNA Bacteria Kit, Blirt S.A., Poland) or RNA (amplified and isolated form E. coli using GeneJET ${ }^{\mathrm{TM}}$ RNA Purification Kit, Thermo Scientific, USA) were digested with 0.01, 0.1 and $1 \mathrm{pg}$ of $P$ inNuc at $30^{\circ} \mathrm{C}$ for $30 \mathrm{~min}$ in reaction buffer consisting of $50 \mathrm{mM}$ Tris- $\mathrm{HCl} \mathrm{pH} 7.5$ and $4 \mathrm{mM} \mathrm{MgCl}_{2}$. The volume of the reaction mixture was $20 \mu \mathrm{l}$. After electrophoretic separation, the obtained products were visualized using ethidium bromide $(1 \mu \mathrm{M})$ under UV light. Additionally, short DNA fragments, both double and single stranded, were digested with PinNuc nuclease at $30{ }^{\circ} \mathrm{C}$ for $30 \mathrm{~min}$, analysed using $4 \%$ agarose gel electrophoresis and visualised as above. ssDNA substrate 5'-F-GAACCAAGTATTCCT CATCGGCACCCTGACCGCCCGCCCC (where F stands for 6-FAM) and poly-thymidine oligonucleotides used for preparation of the size marker, derivatized with fluorescein derivative, were custom-synthesised by Sigma-Aldrich, Poland. ssDNA marker was prepared by mixing $1 \mu \mathrm{l}$ of $10 \mu \mathrm{M}$ solutions of fluorescently labelled (5'-end) poly-thymidine oligonucleotides composed of 10 (dT10), 20 (dT20), 30 (dT30) and 40 (dT40) nucleotides and loaded directly on the gel. dsDNA substrate was prepared as follows: $10 \mu \mathrm{M}$ solutions of oligonucleotides Stab1 (5'-GAACCGGAGGAA TGATGATGATGATGGTGCGGTTTGTCGGACGG) and Stab2 (5'-CCGTCCGACAAACCGCACCATCATCATCAT CATTCCTCCGGTTC) were mixed in 1:1 ratio and incubated at $95^{\circ} \mathrm{C}$ for $2 \mathrm{~min}$. Next, the mixture was allowed to slowly cool down to room temperature (ca. 45-60 min) to yield hybridized dsDNA ready for enzymatic reaction.

\section{Results}

\section{PinNuc Protein Sequence Analysis}

The $P$. ingrahamii 37 genome was sequenced and deposited in the GenBank database by Copeland and co-workers in 2006 [accession number: CP000510.1]. The analysis of the $P$. ingrahamii 37 genome suggested the presence of a gene encoding putative endonuclease I-type nuclease ( $\mathrm{HNH}$ endonuclease [21]). The enzyme, named by us as PinNuc, was chosen as the subject of our studies. On the basis of the gene analysis, it was determined that the PinNuc protein is composed of 256 amino acid residues and has an estimated size of $29.5 \mathrm{kDa}$. The comparison of the amino acid sequence of the PinNuc protein to other proteins from this family revealed moderate sequence identities and similarities. The closest homologues seem to be enzymes from $V$. vulnificus (36\% identity, 52\% similarity) and V. salmonicida (36\% identity, $51 \%$ similarity), both of psychrophilic origin. The most striking difference is the presence of the 13 amino acids long insert in the middle part of protein sequence, where, in most of homologous nucleases, helix 4 is observed (Fig. 1).

An essential element of the comparative analysis of the amino acid sequence is the verification of preserved sites, with important amino acid residues, responsible for performing specific functions of the enzyme. In the case of analysed endonucleases, the essential characteristic features include: the presence of four disulphide bridges, histidine as a general base necessary to activate a water molecule for subsequent phosphate bond hydrolysis, and amino acid residues responsible for binding divalent ions [24].

The analysed sequence was first checked for the presence of conserved domains responsible for the catalytic function of the protein. As it can be seen in Fig. 1, the conserved amino acid motif EWEH, containing two essential residues: metal-binding aspartic acid and catalytic histidine located next to each other, is present in the studied protein in positions 90 (Glu) and 91 (His), respectively. Arginine residue (Arg99 in the nucleases of Vibrio origin), suspected to stabilize the hydrolysis product, is separated by the aforementioned insert, but can be also found in the PinNuc sequence in position 123 (Table 1). 

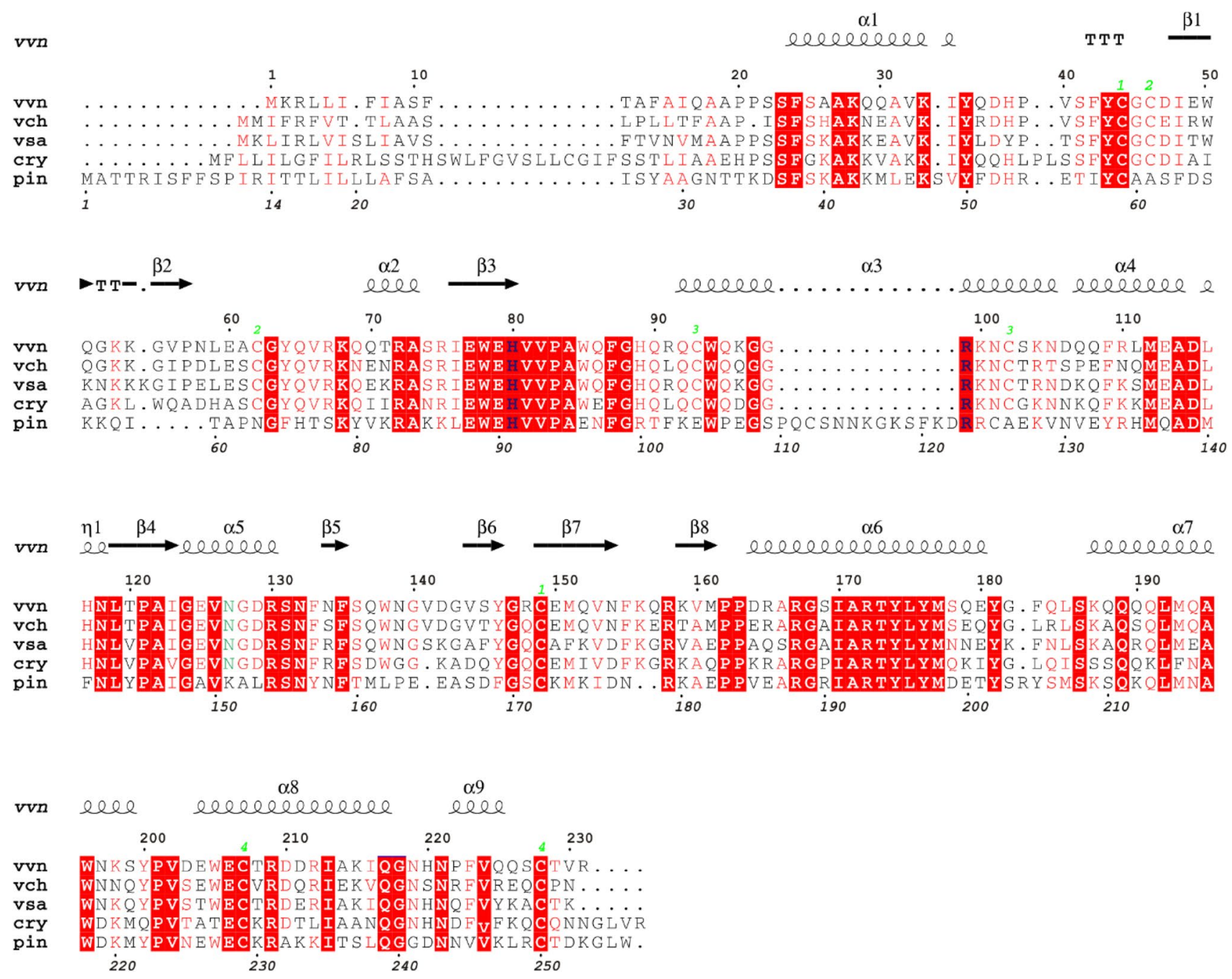

Fig. 1 The multiple amino acid alignment of psychrophilic and mesophilic endonucleases: $v v n$ nuclease form $V$. vulnificus, vch nuclease from $V$. cholerae, vsa nuclease from $V$. salmonicida, pin nuclease from $P$. ingrahamii 37, and cry Cryonase ${ }^{\mathrm{TM}}$ from Shewanella sp. strain AC10. The structural assignment is based on the crystal structure of Vvn nuclease (PDB: 1UOP). Residue numbering on the top

Another important residue, also involved in metal coordination, i.e., asparagine in position 127 (Vvn numbering), in PinNuc is substituted by lysine, which cannot provide proper coordination for $\mathrm{Mg}$ ion (Fig. 1). Therefore, it has to be expected that the metal-ion coordination sphere must be formed differently. Three-dimensional structure of the enzyme is necessary to solve this problem.

The number of disulphide bridges in PinNuc, comparing to other nucleases, is reduced to three. Only first Cys-Cys bond connecting the $\mathrm{N}$ - and $\mathrm{C}$-terminal parts of protein, and the fourth one, located at the very $\mathrm{C}$ terminus, seem to be preserved. Additional disulphide bridge can be found in the insert mentioned above, probably stabilizing a putative loop structure (Table 1). The reduced number of disulphide of each block corresponds to the Vvn nuclease sequence. Numbering for PinNuc is presented on the bottom of each block (italic). Positions of the canonical disulphide bridges are marked with green numbers. His and Arg residues, responsible for the enzymatic activity of proteins, are marked in bold blue. Asn127, involved in metal binding, is marked in green. (Color figure online)

bridges might provide greater protein flexibility at lower temperatures, which is a desirable feature $[25,26]$.

\section{The Cloning, Expression and Purification of PinNuc}

The endonuclease gene from the $P$. ingrahamii was cloned into $\mathrm{pGAPZ} \alpha \mathrm{B}$ plasmid. The resulting construct was inserted into $P$. pastoris GS115 yeast cells, in which an efficient expression of the PinNuc protein was obtained. The presence of the protein was confirmed by the SDS PAGE analysis (Fig. 2a). The optimum expression time was established to be up to 5 days, because longer yeast culturing led to decrease in the recombinant protein content, most likely due to its degradation. The $P$. pastoris overexpression 
Table 1 Positions of amino acid residue characteristic for nucleases endonuclease I type

\begin{tabular}{|c|c|c|c|c|c|c|c|c|c|}
\hline \multirow{3}{*}{$\begin{array}{l}\begin{array}{l}\text { Nuclease/spe- } \\
\text { cies }\end{array} \\
\begin{array}{l}\text { PinNuc } P . \\
\text { ingrahamii }\end{array}\end{array}$} & \multirow[t]{3}{*}{ PDB code } & \multicolumn{8}{|c|}{ Amino acids responsible for } \\
\hline & & \multicolumn{2}{|c|}{$\mathrm{Mg}^{2+}$ binding } & \multicolumn{2}{|c|}{ Catalytic function } & \multicolumn{4}{|c|}{ Disulphide bond formation } \\
\hline & & Glu90a & - & His $91^{\text {a }}$ & $\operatorname{Arg} 123^{\mathrm{a}}$ & $\begin{array}{l}\text { Cys59- } \\
\text { Cys172 }^{\mathrm{b}}\end{array}$ & - & $\begin{array}{l}\text { Cys112- } \\
\text { Cys } 125^{\mathrm{c}}\end{array}$ & Cys229-Cys $250^{\mathrm{b}}$ \\
\hline $\begin{array}{l}\text { Cryonase }^{\mathrm{TM}} \\
\text { Shewanella } \\
\text { sp. strain } \\
\text { AC10 }\end{array}$ & & Glu99 ${ }^{\mathrm{a}}$ & Asn $147^{\mathrm{a}}$ & His $100^{\mathrm{a}}$ & $\operatorname{Arg} 119^{a}$ & $\begin{array}{l}\text { Cys64- } \\
\text { Cys168 }\end{array}$ & Cys66-Cys82 ${ }^{\mathrm{b}}$ & $\begin{array}{l}\text { Cys113- } \\
\text { Cys122 }\end{array}$ & Cys226-Cys $247^{b}$ \\
\hline $\begin{array}{l}\text { Vsa V. salmoni- } \\
\quad \text { cida }\end{array}$ & 2P3U [15] & Glu79 & Asn127 & His80 & Arg99 & Cys44-Cys149 & Cys46-Cys62 & Cys93-Cys102 & Cys207-Cys228 \\
\hline Vch V. cholerae & $\begin{array}{l}\text { 2G7E, 2G7F } \\
{[14]}\end{array}$ & Glu79 & Asn127 & His80 & Arg99 & Cys44-Cys149 & Cys46-Cys62 & Cys93-Cys102 & Cys207-Cys228 \\
\hline$\frac{\text { Vvn }}{c u s}$. vulnifi- & $\begin{array}{l}\text { 1OUO, 1OUP } \\
{[13]}\end{array}$ & Glu79 & Asn127 & His80 & Arg99 & Cys44-Cys149 & Cys46-Cys62 & Cys93-Cys102 & Cys207-Cys228 \\
\hline
\end{tabular}

${ }^{a}$ Based on the sequence homology analysis in Fig. 1

${ }^{\mathrm{b}}$ Conserved, based on the sequence homology analysis in Fig. 1

${ }^{\mathrm{c}}$ New, based on the sequence homology analysis in Fig. 1

system, applied to the studied protein allowed for obtaining of up to $1 \mathrm{mg}$ of PinNuc nuclease from $1000 \mathrm{ml}$ of culture.

\section{Optimization of the Enzymatic Reaction Condition}

Nucleases hydrolyse the phosphodiester bond of nucleic acids. The presence of divalent metal ions is necessary for the nucleic acid hydrolysis reaction for majority of nucleases [9]. Therefore, as a first factor, we decided to check the metal ion-dependency of the PinNuc nuclease activity. The efficiency of DNA digestion in the function of $\mathrm{Mg}^{2+}$, $\mathrm{Mn}^{2+}$ - and $\mathrm{Ca}^{2+}$-ion concentration was examined (Fig. 3).
The reaction was carried out for $30 \mathrm{~min}$ at $30{ }^{\circ} \mathrm{C}$ in the Tris buffer, $\mathrm{pH}$ 7.5. The buffer and $\mathrm{pH}$ value for the initial experiments aiming at the optimization of the PinNuc nucleolytic activity were based on the data for analogous, psychrophilic enzyme Cryonase ${ }^{\mathrm{TM}}$ [11].

The experiment was carried out by supplementing the reaction mixture with selected divalent ion in amounts ranging from 0 to $256 \mathrm{mM}$. The obtained results show unambiguously that the PinNuc nuclease shows the highest activity at low concentrations of divalent ions. The highest levels of substrate digestions were observed upon addition of low (up to $10 \mathrm{mM}$ ) metal ion concentrations. A digestion level

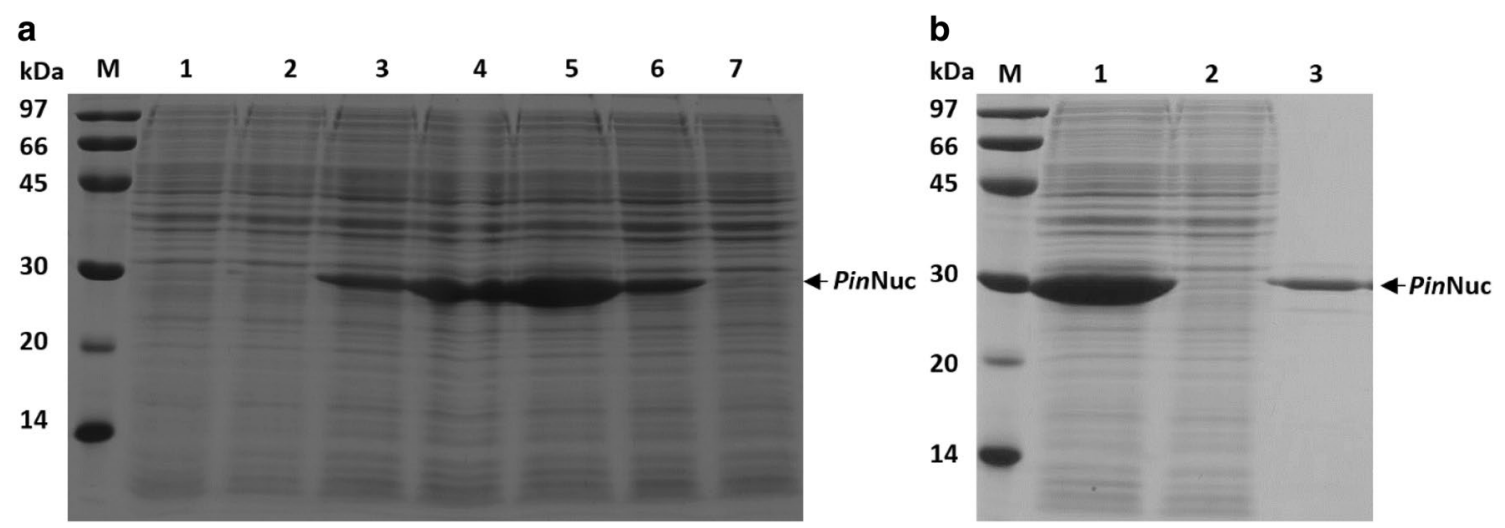

Fig. 2 The expression (a) and purification (b) of PinNuc from Pichia pastoris GS115/pGAPZaB/PinNuc. The proteins were expressed for 6 days and the recombinant protein expression level checked every day. The proteins were analyzed on a $12 \%$ polyacrylamide gel. Position of the PinNuc protein band is marked with an arrow on the right. Lane M: Unstained Protein Weight Marker (GE Healthcare, Product code: 17115001) with the molecular mass of proteins marked on the left; (a) lanes 1-6: cell extracts after 1 day of protein expression (lane 1); 2 days (lane 2); 3 days (lane 3); 4 days (lane 4); 5 days (lane 5) and 6 days (lane 6). Lane 7: expression control P. pastoris GS115 without pGAPZaB/PinNuc; (b) lane 1: crude protein after expression and isolation from $P$. pastoris GS115/pGAPZaB/PinNuc. Lane 2: expression control $-P$. pastoris GS115 without $\mathrm{pGAPZaB/PinNuc}$ $(20 \mu l)$. Lane 3: PinNuc after the $\mathrm{Ni}^{2+}$-affinity chromatography step 

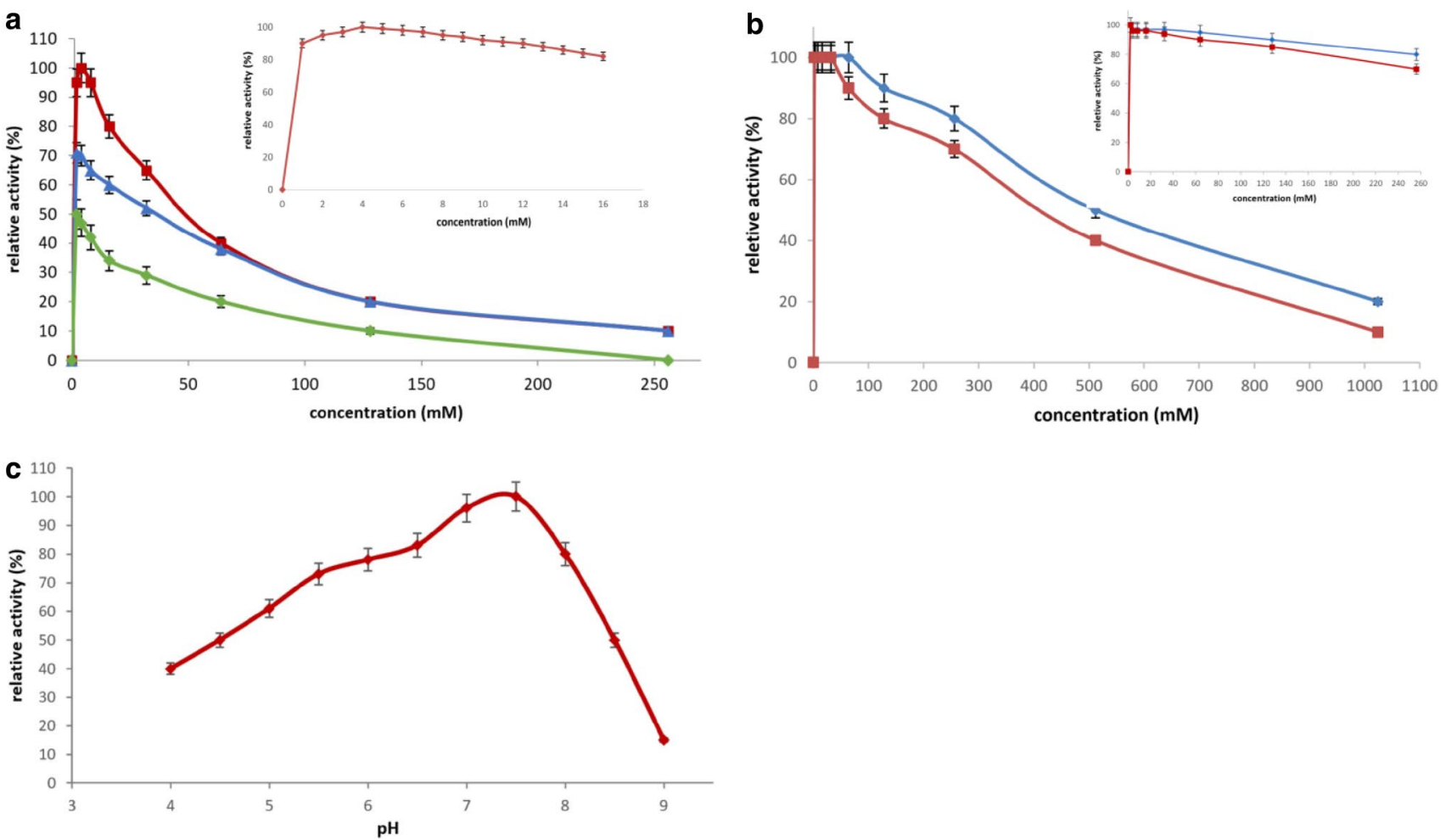

Fig. 3 Optimization of buffer composition for PinNuc nuclease. The effect of (a) divalent ion type and concentration (red squares- $-\mathrm{Mg}^{2+}$, blue dots $-\mathrm{Mn}^{2+}$, and green diamonds- $\mathrm{Ca}^{2+}$ ions); (b) monovalent cations concentration (red squares $-\mathrm{Na}^{+}$, blue dots $-\mathrm{K}^{+}$ions),

of $100 \%$ was obtained by addition of low concentrations of magnesium chloride. Under the same conditions (temperature and time of digestion) and in the presence of $\mathrm{Mn}^{2+}$, a maximum of $70 \%$ degradation of nucleic acids was obtained, while when calcium ions were added-only about $50 \%$ of the DNA was hydrolysed (Fig. 3a).

To determine the exact magnesium concentrations necessary to perform the most effective reaction, a more accurate experiment was carried out. In this assay, lower concentrations of $\mathrm{Mg}^{2+}$ ions, ranging from 0 to $16 \mathrm{mM}$, were tested. PinNuc displays the highest enzymatic activity in the presence of $\mathrm{Mg}^{2+}$ ions at a concentration of $4 \mathrm{mM}$ (Fig. 3a, insert). This value was used for the subsequent experiments.

The structure of nucleases and the mechanism of nucleic acids hydrolysis are very diverse and complex. A contribution of metal ions is required to obtain complete protein activity, as shown in the above experiment. Apart from the divalent ions, intuitively expected to be necessary in reactions involving nucleic acids, monovalent cations such as sodium and potassium, routinely used in buffers to maintain proper ionic strength, might also have an impact on enzyme activity [27]. Therefore, in the following experiment, we tested the impact of the addition of $\mathrm{Na}^{+}$and $\mathrm{K}^{+}$on the efficiency of DNA digestion by PinNuc nuclease (Fig. 3b). and (c) $\mathrm{pH}$ on PinNuc activity. In the insert optimization of PinNuc activity at low $\mathrm{Mg}^{2+}$ (a) and $\mathrm{Na}^{+}$and $\mathrm{K}^{+}$(b) ions concentrations is presented. Error bars represent the deviation from three independent experiments. (Color figure online)

The obtained results indicate that the enzyme efficiently digests nucleic acids in the presence of low concentrations of monovalent ions. The higher the concentration of $\mathrm{Na}^{+}$ and $\mathrm{K}^{+}$in the reaction mixture, the lower the efficiency of DNA hydrolysis by PinNuc. It was also noted that even very high concentrations of monovalent ions do not inhibit completely protein activity. Based on the obtained results, we decided to omit the addition of monovalent ions to the reaction mixtures.

The enzyme activity depends also on the $\mathrm{pH}$ of the buffer in which the reaction is carried out [28]. Therefore, the dependency of DNA digestion by PinNuc of the $\mathrm{pH}$ of the reaction buffer was examined. The obtained results (Fig. 3c) indicate that PinNuc nuclease shows an activity over a broad $\mathrm{pH}$ range (4.0-9.0). In slightly acidic buffer $(\mathrm{pH}$ 4.0 ), the enzyme activity is moderate and does not exceed $40 \%$ of the maximum value. The activity increases with the increase of the $\mathrm{pH}$ of the buffer, reaching the maximum at $\mathrm{pH}$ 7.5. Further change of the $\mathrm{pH}$ towards more alkaline leads to the decline in enzyme activity (Fig. 3c). At pH 9.5, complete inhibition of the enzyme was observed. Based on the obtained data, a $\mathrm{pH}$ value 7.5 of the reaction that was chosen for initial experiments was proper and can be used in further analyses. Therefore, the optimum reaction buffer 
composition was determined as follows: $50 \mathrm{mM}$ Tris- $\mathrm{HCl}$, $\mathrm{pH} 7.5$, and $4 \mathrm{mM} \mathrm{MgCl} 2$.

\section{Effect of Temperature on PinNuc Activity. Inactivation of the Enzyme}

An important element in optimising the conditions of nuclease digestion of DNA is to determine the temperature range in which the protein displays the highest activity. All above experiments were performed at a temperature of $30{ }^{\circ} \mathrm{C}$, which was selected based on the manufacturer suggestions for analogous psychrophilic enzyme, Cryonase ${ }^{\mathrm{TM}}$. It is, however, worth checking if this temperature is indeed also optimal for our enzyme, and the temperature dependence of the PinNuc nuclease activity itself.

The results of this experiment revealed that, under the optimal buffer conditions of DNA hydrolysis $(50 \mathrm{mM}$ Tris- $\mathrm{HCl} \mathrm{pH} 7.5$, and $4 \mathrm{mM} \mathrm{MgCl}_{2}$ ), PinNuc nuclease completely digests DNA at a wide range of temperatures $\left(15-45^{\circ} \mathrm{C}\right)$ (Fig. $\left.4 \mathrm{a}\right)$. With the aim to capture the difference in digestion, the protein preparation was diluted, and an activity test was carried out. An eightfold dilution allowed for observation of a difference in the level of DNA digestion. As the temperature rises from 15 to $35^{\circ} \mathrm{C}$, so increases the level of DNA digestion. The most effective digestion is observed at $35^{\circ} \mathrm{C}$. Further increase of the temperature (to 40,45 and $50{ }^{\circ} \mathrm{C}$ ) leads to slight decrease in the digestion efficiency and quality (Fig. 4b).

\section{a}

Incubation

$\begin{array}{lllllllllll}\text { temperature }\left[{ }^{\circ} \mathrm{C}\right] & \mathrm{C} & 10 & 15 & 20 & 25 & 30 & 35 & 40 & 45 & 50\end{array}$

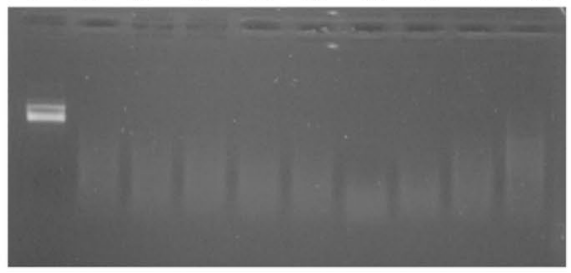

C

$\begin{array}{llllllll}\text { Incubation time }[\mathrm{min}] & \text { control } & 0 & 5 & 15 & 30 & 45 & 60\end{array}$

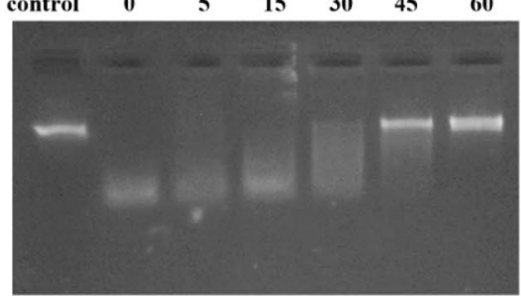

Fig. 4 Effect of temperature and redox conditions on PinNuc endonuclease activity. The impact of temperature on the nucleolytic activity of concentrated (a) and diluted (b) PinNuc sample; (c) thermostability of the enzyme during incubation at $99{ }^{\circ} \mathrm{C}$, and (d) the impact of the temperature of incubation in the presence of $1 \mathrm{mM}$ of DTT. $77 \mathrm{ng}$
The activity of PinNuc at low temperature regimes was also tested and it was observed that it is able to digest DNA at temperatures as low as $+4{ }^{\circ} \mathrm{C}$ (data not shown).

Even though the PinNuc nuclease is intended to work at lower temperature regimes, its thermostability does not seem to be a critical feature, the temperature can be used for its deliberate inactivation after the completion of its task in the reaction mixture. For many nucleases active at ambient temperatures (around $37{ }^{\circ} \mathrm{C}$ ), for example restriction enzymes, heat inactivation is a convenient method for stopping the enzymatic reaction. For enzymes that are heatinsensitive (for example, RNAse A), external compounds (metal ions chelators, reducing agents, denaturants, DEPC, specific inhibitors) must be added, or the enzyme removed physically, using either chromatography mini-columns, electrophoresis or extraction. For an enzyme originating from a psychrophilic organism, heat inactivation can be expected. For example, close analogue of the PinNuc nuclease, Cryonase $^{\mathrm{TM}}$, can be completely inactivated after a $30-\mathrm{min}$ incubation at $70{ }^{\circ} \mathrm{C}[11]$.

The thermostability analysis of the PinNuc protein was performed in two approaches. In the first one, the enzyme was incubated at $99^{\circ} \mathrm{C}$ for $5,15,30,45$ and $60 \mathrm{~min}$, and the activity test at previously optimized conditions was performed. This experiment showed that the PinNuc protein is thermally very stable, and only after 60 min of incubation at $99{ }^{\circ} \mathrm{C}$ loses its activity (Fig. 4c). The possibility of protein inactivation is extremely important to stop the DNA

\section{b}

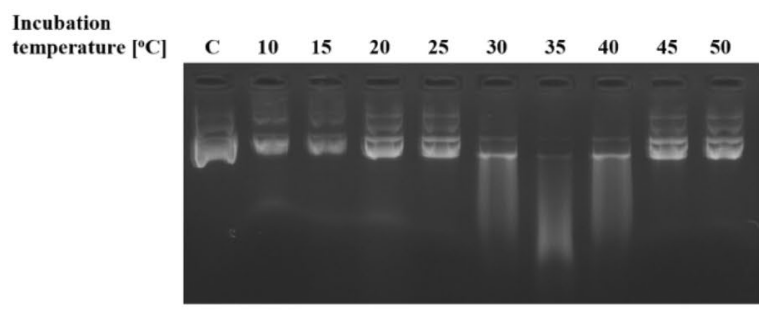

d

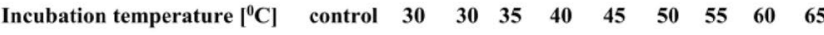
Incubation time [min]

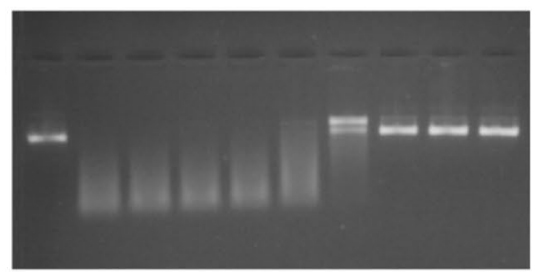

of plasmid DNA (pUC19) was digested in each reaction and the results were analyzed using $1 \%$ agarose gel electrophoresis in TAE buffer in the presence of $1 \mu \mathrm{M}$ ethidium bromide. Control-DNA without nuclease treatment 
hydrolysis reaction in a controlled manner. The obtained result was, therefore, not very promising in this context.

In the next step, enzyme stability was tested upon addition of DTT at various concentrations and subsequent incubation at $99{ }^{\circ} \mathrm{C}$. The experiment was carried out simultaneously for two reducing agent concentrations: $1 \mathrm{mM}$ and $5 \mathrm{mM}$. The obtained results revealed that addition of DTT at a low concentration $(1 \mathrm{mM})$ completely deactivates PinNuc enzymatic activity after a short (20 min) incubation at a high temperature (data not shown).

Since the addition of the reducing agent significantly alters the protein activity, it seemed reasonable to check the temperature dependence of this phenomenon. Therefore, in the next experiment, $1 \mathrm{mM}$ of DTT was added to the preparation, the incubation temperature was lowered, and the denaturation time was reduced. The efficiency of the nuclease inactivation at these conditions was tested using a standard activity test. This experiment showed that incubation at $50{ }^{\circ} \mathrm{C}$ inactivates the protein in about $90 \%$. Raising the temperature to $55{ }^{\circ} \mathrm{C}$ causes complete inactivation of the nuclease (Fig. 4d). Control experiment, carried out without the addition of $1 \mathrm{mM}$ of DTT, confirmed that the observed effect is solely imposed by the presence of reducing agent (data not shown). In conclusion, it can be stated that PinNuc nuclease activity can be very effectively controlled by the addition of a reducing agent and short incubation at a slightly increased (as compared to the enzymatic reaction conditions) temperature.

\section{Substrate Specificity the PinNuc Nuclease}

To avoid an unwanted or uncontrolled degradation reaction of DNA and RNA in cells, nuclease activity must be strictly regulated by the specific nature of the substrate, limited location, or strong inhibitors. To check the substrate specificity of PinNuc nuclease, different forms and types of nucleic acids were tested. The digestion efficiency of genomic
DNA, plasmid DNA, ssDNA, RNA and the PCR product was examined (Figs. 5a-d, 6a, b).

The obtained results indicate that, similarly to other nucleases belonging to the endonuclease I family, PinNuc also does not show distinct substrate specificity. It recognizes and efficiently digests both types of nucleic acids as well as different forms of them. The cleavage is unspecific and yields short fragments that either form long smears or elute from gels (with lower agarose concentration). Application of more dense gels (4\%) and digestion of fluorescently labelled substrate (Fig. 6a, b) allowed to estimate that these fragments might be shorter than 8-10 nucleotides. The obtained nuclease seems to be more efficient in the digestion of genomic, dsDNA than ssDNA (Fig. 6).

\section{Discussion}

The experiments presented in this study concern cloning, expression, purification, and characterisation of a nuclease from an extremely psychrophilic strain $P$. ingrahamii. Currently, three nucleases that degrade all forms of nucleic acids are commercially available, namely Cryonase ${ }^{\mathrm{TM}}$ obtained from the psychrotrophic strain Shewanella sp., Benzonase ${ }^{\circledR}$ from the mesophilic organism S. marcescens and HL-SAN of unrevealed origin. Our results have the potential to extend this collection by the addition of a homologous enzyme from a psychrophilic organism.

The gene encoding putative endonuclease I was integrated with DNA of $P$. pastoris, efficiently expressed and purified to homogeneity. It is worth to mention at this point that we have initially tried to obtain PinNuc nuclease using prokaryotic expression system (E. coli BL21(DE3), E. coli BL21(DE3)pLysS, E. coli Rosetta(DE3), E. coli Rosetta(DE3)pLacI, E. coli Artic Express) but the expression was inefficient due to either low periplasmic expression levels or difficulties with protein purification and refolding

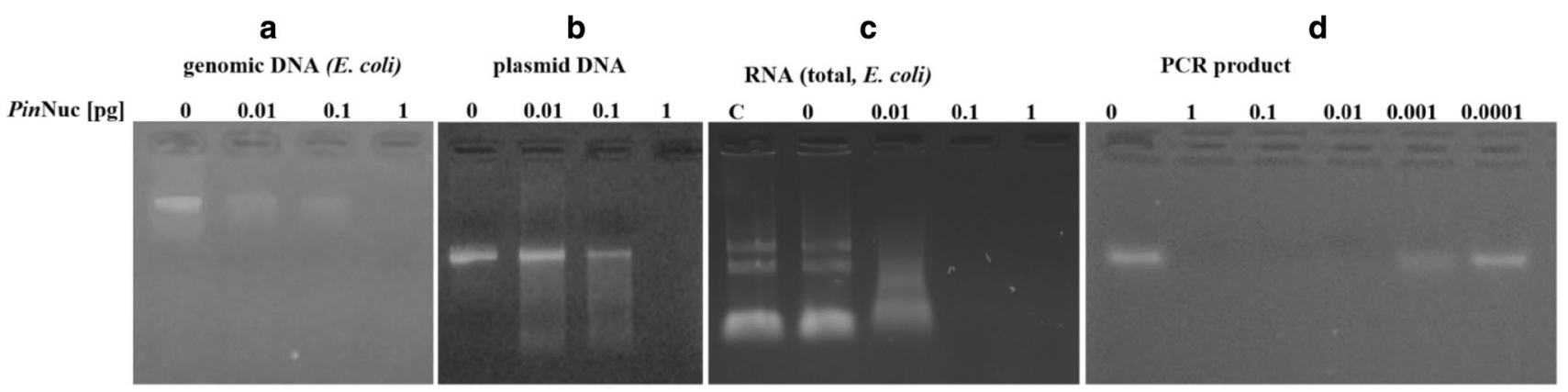

Fig. 5 Activity of the obtained nuclease depending on the substrate. Different forms of DNA (genomic, plasmid, and PCR product) and RNA were digested with varying concentrations of PinNuc nuclease at $30{ }^{\circ} \mathrm{C}$ for $30 \mathrm{~min}$. RNA sample was additionally incubated with inactivated (with DTT) PinNuc nuclease to exclude the possibility of contamination with extrinsic RNAses (line C). $20 \mu$ of each sample was next analyzed using $1 \%$ (a-c) or $2 \%$ (d) agarose gel electrophoresis in TAE buffer in the presence of $1 \mu \mathrm{M}$ ethidium bromide 
Fig. 6 Digestion of short DNA forms with PinNuc nuclease. DNA samples (dsDNA and ssDNA) were digested with varying concentrations of PinNuc nuclease at $30^{\circ} \mathrm{C}$ for $30 \mathrm{~min} .20 \mu \mathrm{l}$ of each sample was next analyzed using $4 \%$ gel electrophoresis in TAE buffer in the presence of $1 \mu \mathrm{M}$ ethidium bromide a

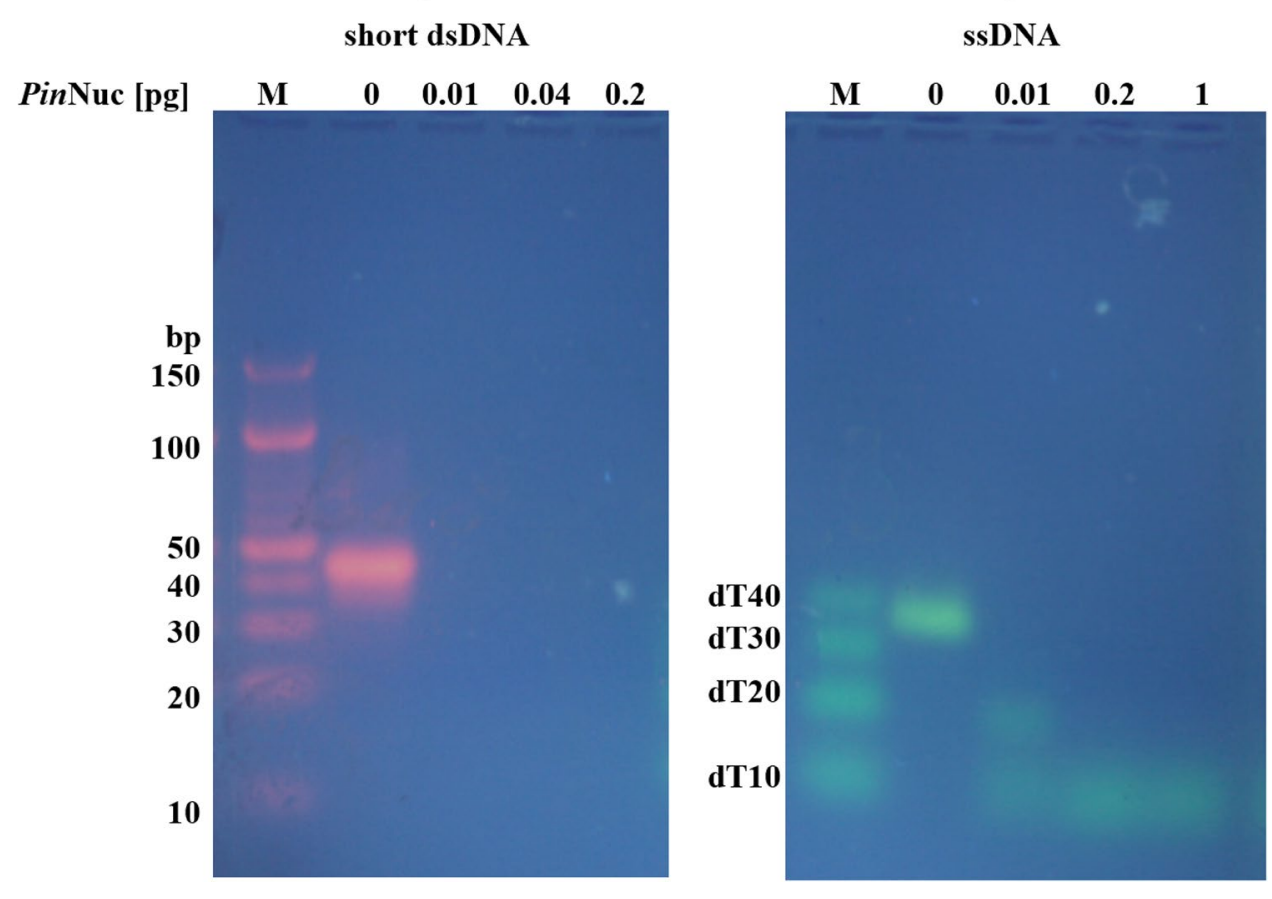

from inclusion bodies after cytoplasmic expression. Even application of the chaperone system (GroEL/GroES/DnaK/ DnaJ/GrpE, Takara Chaperone Plasmid Set Cat. \#3340) did not improve the results significantly (N. Maciejewska, unpublished data).

Analysis of the nucleotide sequence of the PinNuc protein indicated the presence of a domain characteristic for the nonspecific endonucleases from family I [21], found in mesophilic and psychrophilic microorganisms. These nucleases are periplasmic or secreted enzymes known to non-specifically degrade both RNA and DNA by hydrolysis of the bond between the 5'-phosphate and 3'-sugar moiety, generating short oligonucleotide fragments [24]. Subsequent cloning end expression of this gene yielded protein consisting of 256 amino acid residues with the molecular mass of approximately $29.5 \mathrm{kDa}$, which was confirmed by electrophoresis. Amino acid analysis and alignment with the most typical nucleases from this family (Vvn from $V$. vulnificus, Vch from $V$. cholerae, Vsa from $V$. salmonicida, as well as commercially available Cryonase ${ }^{\mathrm{TM}}$ ) obtained from mesophilic or psychotropic microorganisms revealed moderate (ca. 50\%) sequence similarity. The differences in the amino acid composition most likely arise from the adjustment of the $P$. ingrahamii to its natural habitat which is more extreme (temperature-wise) than that for other psychrophilic organisms. As it was already mentioned, $P$. ingrahamii it not only able to survive but also can proliferate at temperatures below $-10{ }^{\circ} \mathrm{C}$, which is the lowest observed temperature for any organism. Therefore, it might be expected that the bacterium had to adapt to such a feature, for example, by optimizing the composition of its proteins (and other biomolecules) [29, 30]. Regardless of the differences, the most important domains, responsible for the catalytic activity of the enzyme, are conserved in PinNuc.

PinNuc has the ability to degrade all forms of nucleic acids (Figs. 5, 6). The enzyme hydrolyses DNA and RNA to small fragments. An amount of $1 \mu \mathrm{l}$ of PinNuc protein at a concentration of $1 \mu \mathrm{g} / \mathrm{ml}$ completely degrades $200 \mathrm{ng}$ of genomic DNA in $30 \mathrm{~min}$. Larger protein dilutions $\left(\times 10^{-4}\right)$ do not inhibit the activity, but only reduce the digestive efficiency to about $80 \%$. The protein is active in a wide range of temperature conditions, although it operates most effectively in the range of around $35^{\circ} \mathrm{C}$. Optimal conditions for hydrolysis of nucleic acids by PinNuc were established and they require the presence of $4 \mathrm{mM} \mathrm{Mg}$ (II) ions and buffer at $\mathrm{pH}$ 7.5. These conditions are, therefore, similar to those recommended for commercial nucleases.

The tested enzyme is exceptionally thermally stable. Incubation of the protein at a temperature of $99{ }^{\circ} \mathrm{C}$ for a duration of 45 min does not completely inhibit its activity. This is a rather remarkable feature, considering the origin of this enzyme. Other nucleases can be inactivated by heating to $70{ }^{\circ} \mathrm{C}$ for $30 \mathrm{~min}$ (Cryonase ${ }^{\mathrm{TM}}$ [11]) or by addition of external compounds such as denaturing agents, chelators, monovalent cations, or phosphate ions (Benzonase ${ }^{\circledR}$ ). PinNuc protein, on the other hand, can be completely deactivated by incubating the preparation for $15 \mathrm{~min}$ at $55^{\circ} \mathrm{C}$ in the presence of $1 \mathrm{mM}$ of DTT. This is a very interesting feature, providing an alternative to already-known enzymes of this type (Cryonase ${ }^{\mathrm{TM}}$ is reported to withstand DTT 
concentration up to $167 \mathrm{mM}$, whereas Benzonase ${ }^{\circledR}$ —up to $100 \mathrm{mM}$ ). PinNuc can, therefore, be a very attractive tool in molecular biology and genetic engineering. Possible application of PinNuc may include, but do not need to be limited to, purification of protein preparations from nucleic acids at every stage of their preparation without affecting their performance, decreasing the viscosity of protein preparations, removal of genomic DNA or RNA or removal of the DNA template from the PCR reaction.

Research on the PinNuc protein will continue in the future. The potential applications of the enzyme in the biotechnology and pharmaceutical industry, in the PCR reaction, in bi-directional electrophoresis, expression and purification of proteins, synthesis of DNA libraries, ELISA tests, and the Western blot will be investigated.

In our opinion, it is still worth optimising the conditions for the degradation of nucleic acids with the use of PinNuc to lower the reaction temperature. The extremely low living temperature of the $P$. ingrahamii host gives the basis for the possibility of elaboration of reaction conditions enabling efficient and fast degradation of DNA and RNA at lower temperatures, preferably below $10{ }^{\circ} \mathrm{C}$. The prospects of such discovery would be very attractive for future industrial application of our enzyme.

Acknowledgements Work supported by National Science Center, Poland Grant PRELUDIUM I, No. 2011/01/N/NZ1/01569 to Natalia Maciejewska.

\section{Compliance with Ethical Standards}

Conflict of interest The authors declare no conflict of interest.

Ethical Approval This article does not contain any studies with human participants or animals performed by any of the authors.

Informed Consent Informed consent was obtained from all individual participants included in the study.

Open Access This article is distributed under the terms of the Creative Commons Attribution 4.0 International License (http://creativeco mmons.org/licenses/by/4.0/), which permits unrestricted use, distribution, and reproduction in any medium, provided you give appropriate credit to the original author(s) and the source, provide a link to the Creative Commons license, and indicate if changes were made.

\section{References}

1. Rodrigues, D. F., \& Tiedje, J. M. (2008). Coping with our cold planet. Applied and Environmental Microbiology, 74(6), 16771686. https://doi.org/10.1128/AEM.02000-07.

2. Struvay, C., \& Feller, G. (2012). Optimization to low temperature activity in psychrophilic enzymes. International Journal of Molecular Sciences, 13(9), 11643-11665. https://doi.org/10.3390/ ijms130911643.
3. Javed, A., \& Iqbal, J. (2016). Psychrophilic microbial enzymes implications in coming biotechnological processes. American Scientific Research Journal for Engineering, Technology, and Sciences (ASRJETS), 23(1), 103-120.

4. Sarmiento, F., Peralta, R., \& Blamey, J. M. (2015). Cold and hot extremozymes: Industrial relevance and current trends. Frontiers in Bioengineering and Biotechnology, 3, 148. https://doi. org/10.3389/fbioe.2015.00148.

5. Banerjee, R., Halder, A., \& Natta, A. (2016). Psychrophilic microorganisms: Habitats and exploitation potentials. European Journal of Biotechnology and Bioscience, 4(3), 16-24.

6. Chen, G.-Q., \& Jiang, X.-R. (2018). Next generation industrial biotechnology based on extremophilic bacteria. Current Opinion in Biotechnology, 50, 94-100. https://doi.org/10.1016/J. COPBIO.2017.11.016.

7. Margesin, R., \& Feller, G. (2010). Biotechnological applications of psychrophiles. Environmental Technology, 31(8-9), 835-844. https://doi.org/10.1080/09593331003663328.

8. Cavicchioli, R., Charlton, T., Ertan, H., Mohd Omar, S., Siddiqui, K. S., \& Williams, T. J. (2011). Biotechnological uses of enzymes from psychrophiles. Microbial Biotechnology, 4(4), 449-460. https://doi.org/10.1111/j.1751-7915.2011.00258.x.

9. Yang, W. (2011). Nucleases: Diversity of structure, function and mechanism. Quarterly Reviews of Biophysics, 44(1), 1-93. https://doi.org/10.1017/S0033583510000181.

10. Pan, Y., Xiao, L., Li, A. S. S., Zhang, X., Sirois, P., Zhang, J., \& Li, K. (2013). Biological and biomedical applications of engineered nucleases. Molecular Biotechnology, 55(1), 54-62. https://doi.org/10.1007/s12033-012-9613-9.

11. Awazu, N., Shodai, T., Takakura, H., Kitagawa, M., Mukai, H., \& Kato, I. (2011). Microorganism-derived psychrophilic endonuclease. Patent US 2009/0047705 A1. https://patents.googl e.com/patent/US8034597.

12. Wu, S., Lo, S., Shao, C., \& Tsai, H. (2001). Cloning and characterization of a periplasmic nuclease of vibrio vulnificus and its role in preventing uptake of foreign DNA cloning and characterization of a periplasmic nuclease of vibrio vulnificus and its role in preventing uptake of foreign DNA. Applied and Environmental Microbiology, 67(1), 82-88. https://doi.org/10.1128/ AEM.67.1.82.

13. Li, C.-L., Hor, L.-I., Chang, Z.-F., Tsai, L.-C., Yang, W.-Z., \& Yuan, H. S. (2003). DNA binding and cleavage by the periplasmic nuclease Vvn: A novel structure with a known active site. The EMBO Journal, 22(15), 4014-4025. https://doi. org/10.1093/emboj/cdg377.

14. Altermark, B., Smalås, A. O., Willassen, N. P., \& Helland, R. (2006). The structure of Vibrio cholerae extracellular endonuclease I reveals the presence of a buried chloride ion. Acta Crystallographica Section D: Biological Crystallography, 62(11), 1387-1391. https://doi.org/10.1107/S0907444906034196.

15. Altermark, B., Helland, R., Moe, E., Willassen, N. P., \& Smalås, A. O. (2008). Structural adaptation of endonuclease I from the cold-adapted and halophilic bacterium Vibrio salmonicida. Acta Crystallographica Section D: Biological Crystallography, 64(4), 368-376. https://doi.org/10.1107/S0907444908000097.

16. Shlyapnikov, S. V., Lunin, V. V., Perbandt, M., Polyakov, K. M., Lunin, V. Y., Levdikov, V. M., ... Mikhailov, A. M. (2000). Atomic structure of the Serratia marcescens endonuclease at 1.1 $\AA$ resolution and the enzyme reaction mechanism. Acta Crystallographica Section D: Biological Crystallography, 56(5), 567-572. https://doi.org/10.1107/S090744490000322X.

17. Jekel, M., \& Wackernagel, W. (1995). The periplasmic endonuclease I of Escherichia coli has amino-acid sequence homology to the extracellular DNases of Vibrio cholerae and Aeromonas hydrophila. Gene, 154(1), 55-59. 
18. Gosink, J. J., Irgens, R. L., \& Staley, J. T. (1993). Vertical distribution of bacteria in arctic sea ice. FEMS Microbiology Letters, 102(2), 85-90. https://doi.org/10.1111/j.1574-6968.1993.tb057 99.x.

19. Breezee, J., Cady, N., \& Staley, J. T. (2004). Subfreezing growth of the sea ice bacterium Psychromonas ingrahamii. Microbial Ecology, 47(3), 300-304. https://doi.org/10.1007/s0024 8-003-1040-9.

20. Auman, A. J., Breezee, J. L., Gosink, J. J., Kämpfer, P., \& Staley, J. T. (2006). Psychromonas ingrahamii sp. nov., a novel gas vacuolate, psychrophilic bacterium isolated from Arctic polar sea ice. International Journal of Systematic and Evolutionary Microbiology, 56(5), 1001-1007. https://doi.org/10.1099/ijs.0.64068-0.

21. Riley, M., Staley, J. T., Danchin, A., Zhang, T. Z., Brettin, T. S., Hauser, L. J., ... Thompson, L. S. (2008). Genomics of an extreme psychrophile, Psychromonas ingrahamii. BMC Genomics, 9, 1-19. https://doi.org/10.1186/1471-2164-9-210.

22. Boratyn, G. M., Camacho, C., Cooper, P. S., Coulouris, G., Fong, A., Ma, N., ... Zaretskaya, I. (2013). BLAST: A more efficient report with usability improvements. Nucleic Acids Research, 41(Web Server issue), 29-33. https://doi.org/10.1093/nar/gkt282.

23. Robert, X., \& Gouet, P. (2014). Deciphering key features in protein structures with the new ENDscript server. Nucleic Acids Research, 42(W1), W320-W324. https://doi.org/10.1093/nar/ gku316.

24. Michetti, D., Brandsdal, B. O., Bon, D., Isaksen, G. V., Tiberti, M., \& Papaleo, E. (2017). A comparative study of cold- and warm-adapted Endonucleases A using sequence analyses and molecular dynamics simulations. PLoS ONE, 12(2), e0169586. https://doi.org/10.1371/journal.pone.0169586.

25. D’Amico, S., Collins, T., Marx, J.-C., Feller, G., \& Gerday, C. (2006). Psychrophilic microorganisms: Challenges for life. EMBO Reports, 7(4), 385-389. https://doi.org/10.1038/sj.embor.74006 62.

26. De Maayer, P., Anderson, D., Cary, C., \& Cowan, D. A. (2014). Some like it cold: Understanding the survival strategies of psychrophiles. EMBO Reports, 15, 508-517. https://doi.org/10.1002/ embr.201338170.

27. Gohara, D. W., \& Di Cera, E. (2016). Molecular mechanisms of enzyme activation by monovalent cations. The Journal of Biological Chemistry, 291(40), 20840-20848. https://doi.org/10.1074/ jbc.R116.737833.

28. Bisswanger, H. (2014). Enzyme assays. Perspectives in Science, 1(1-6), 41-55. https://doi.org/10.1016/J.PISC.2014.02.005.

29. Metpally, R. P. R., \& Reddy, B. V. B. (2009). Comparative proteome analysis of psychrophilic versus mesophilic bacterial species: Insights into the molecular basis of cold adaptation of proteins. BMC Genomics, 10(1), 11. https://doi. org/10.1186/1471-2164-10-11.

30. Altermark, B., Thorvaldsen, S., Moe, E., Smalås, A. O., \& Willassen, N. P. (2007). Sequence comparison and environmental adaptation of a bacterial endonuclease. Computational Biology and Chemistry, 31(3), 163-172. https://doi.org/10.1016/j.compb iolchem.2007.03.003. 